\title{
Consumption Behavior of Street Foods among the Young Consumers and Microbial Assessment of Street Food in Dhaka City
}

\author{
Sumaiya Mamun ${ }^{1}$, Sabiha Alam¹ ${ }^{1}$, Mohammad Abduz Zaher ${ }^{1}$, Mohammad Rahanur Alam² \\ ${ }^{1}$ Institute of Nutrition and Food Science, University of Dhaka, Dhaka-1000. ${ }^{2}$ Noakhali University of Science and Technologies, Noakhali, Bangladesh.
}

\begin{abstract}
Street foods are widely consumed all over the world as well as Dhaka city. To determine the preferences for these foods, a cross-sectional study was conducted among 645 individuals constituted by randomly selected high school and university students. Also, samples were examined to identify the presence of microorganisms to detect contamination. Of the participants, $40 \%$ were male and $60 \%$ were female; the majority of them were between 19 and 22 years of age. It was found that $15.81 \%$ of the young people conjume street food 2-3 times per week, whereas $48.37 \%$ were found to have it every day. Shingara $(n=411,63.72 \%)$, Samucha $(n=267,41.40 \%)$, Puri $(n=225$, $\mathbf{3 4 . 8 8 \%}$ ), and Fuchka $(\mathrm{n}=\mathbf{2 1 6}, \mathbf{3 3 . 4 8 \%})$ are the most preferred street foods among young people. In microbial assessment, velpuri had the highest amount of Staphylococcus spp. $\left(5.3 \times 10^{5}\right.$ c.f.u. per $\left.\mathrm{gm}\right)$, fuchka contained the highest amount of Salmonella spp. (4.1 x $10^{5}$ c.f.u. per gm) and jhalmuri had the highest number of $E$. coli $\left(4.0 \times 10^{4}\right.$ c.f.u. per gm). Consumers prefer street food because of their low cost, varieties, taste, availability and fast service. The results of our study indicated that most of the Ready to Eat (RTE) food samples tested did not meet bacteriological quality standards. Young people frequently consume the street foods in Dhaka city. To prevent food poisoning and other microbial diseases they should be educated about food hygiene and safety. The contamination risk can be minimized by providing knowledge about personal hygiene and good manufacture practice to the vendors.
\end{abstract}

Key words: Street food, Food preference, microorganisms.

\section{Introduction}

Foodborne diseases and food safety is an international public health concern. Changes in microorganisms and new chemicals associated with food is a continuous challenge around the world. There are also risks related to food production techniques and consumer behaviours. The potential for international incidents involving contaminated food are increasing due to the rapid globalization of food production and trade. Gradually it is becoming a global concern ${ }^{1}$. Street foods are pre-processed or prepared foods and beverages usually sold in the street and other open public spaces and that are ready to consume ${ }^{2}$. Street foods are generally available in busy places (on street corners, at interchanges, subway station entrances/exits, crossroads etc. $)^{3}$. Each street food enterprise usually needs a small amount of capital to start with and requires very basic skills and basic facilities. As such they hold tremendous potential for generating income and employment for the rapidly rising urban population of Dhaka city, the capital of Bangladesh. In developing countries most of the disposable income is spent on food consumption and busy schedules made street foods into another popular source of nutrition.

Almost 2.5 billion people around the globe consume street food ${ }^{2}$. It is stated that approximately 30 million people in Bangladesh suffer from foodborne illnesses each year, raises the importance of food safety and its relation to health ${ }^{1}$. There are reports of many epidemiological studies about the relation of street food and diseases reflecting lack of knowledge about hygiene and food safety of street food sellers and the overabundance of pathogenic bacteria in street food samples ${ }^{2}$. In many countries around the world, especially in Africa, Asia, and Latin America, it has been found that street foods carry harmful pathogens and cause serious foodborne diseases ${ }^{4-8}$.

Contaminated street foods significantly contribute to foodborne illnesses. Lack of education and the knowledge about handling practice, sanitation and hygiene of the vendors easily contaminate food $^{9}$. There are several reason for contamination of street fast foods includes the utensils and equipment that enhance cross contamination, vending sites that are filthy in nature, type of water used in preparation of food, waste product of restaurants that attract the rodents and insects which may carry foodborne pathogens, flies that land on food sporadically and finally handling of food by vendors with bare hands ${ }^{10}$.

To sell food products at low cost and more profit, vendors often purchase raw materials from various sources which may either be contaminated or unfit for consumption ${ }^{11}$.Vendors generally use carts and stands, where they do not have easy access to running water, furthermore same bucket is used for dish and hand washing, sometimes without soap or detergent. Poor waste and water

Corresponding author:

Sumaiya Mamun, Assistant Professor, Institute of Nutrition and Food Science, University of Dhaka.

email: sumaiya.mamun@gmail.com 
disposal system in the streets attracts rodents and insects. Unavailability of toilets forces the vendors to dispose of body wastes in nearby areas and return to their vending sites without washing their hands ${ }^{12}$. Foodborne illnesses occur after consumption of contaminated foods and/ or their preformed toxins ${ }^{13}$. In the food preparation, storage, and service stages the contamination of foods with hazardous microorganisms such as E. coli, Salmonella Typhimurium, Pseudomonas spp., Staphylococcus aureus, and Proteus spp. have damaging consequences to the human body.

Reports have suggested that enteropathogenic E. coli (EPEC) is a predominant cause of diarrhoea in Bangladesh and is spread through contaminated water and food ${ }^{14}$. Although there is a growing demand for RTE food products, no recent information is available regarding the microbiological quality of these products in Dhaka city, Bangladesh. The present study was undertaken to analyze the behavioral pattern and determine the microbiological quality and safety of street food typically consumed by young consumers in Dhaka city.

\section{Methods}

\section{Data collection}

The study was a cross-sectional descriptive study. Six hundred and forty five young volunteer consumers $($ male $=258$, female $=$ 387) who were either high school (15-19 years old) or university students ( $>19$ years old) were selected for the study. The data of the study were collected with a self-administrable questionnaire developed by the researchers between February and August 2018 in Dhaka. Informed consent was taken from all the subjects through voluntary participation form and filled in the questionnaire, which adhered to the principles of the Declaration of Helsinki (World Medical Association).

A pilot study on 74 consumers was conducted and then suitable modifications were made to the questionnaire. The questionnaire was organized into two main sections; i) Demographic information, ii) Consumers' decisions regarding street food preferences and preference causes. The demographic information included gender, age, income, and educational background. The participants were asked to indicate their favorite five items from the list of 45 street foods mostly consumed in Dhaka. The questions asked were from the following categories: food safety knowledge, food purchase decisions, factors influencing food choices, concerns about food safety of street foods and attitudes towards food safety regarding street food. The factors influencing food choices were designed based on food choice questionnaires developed by other researchers, including convenience, sensory appeal (appearance, taste, smell, texture, and sound), price, nutritional value, mood, familiarity, the appearance of street food, and safety. A five-point Likert scale, ranging from one (1) 'strongly disagree' to five (5) 'strongly agree' was also used to determine respondents' attitudes towards street food safety and the reasons for choosing street foods among 25 items. Total street food preference score obtained from questions ranged between 25-125 with every item score ranging between $1-5$. Rising of the total score indicated that there are more causes to prefer street foods over healthy food.

\section{Microbiological examination}

\section{Sample collection}

A total of 28 samples were collected for bacteriological examination. The street vendors on the busiest street areas were chosen for sample collection. The samples were congregated during the months of February to August 2018, when the average ambient temperature in Dhaka is $30-32 \pm 0.5^{\circ} \mathrm{C}$. The food samples were collected from vendors on Sunday afternoon between 10:30 and $12: 30 \mathrm{pm}$. The time interval between sampling from each vendor was approximately 25 minutes. Eight samples were collected on every sampling day. Approximately $300 \mathrm{~g}$ of each food sample was collected into sterile plastic bags. Food temperatures were recorded at the time of sampling using a portable thermometer. All the collected samples were kept on an ice-box during transportation to the laboratory and stored at $4{ }^{\circ} \mathrm{C}$ until testing. They were analyzed within 24 hours of sampling.

\section{Processing of Samples}

Before analysis, 10 gms of each sample were added to $90 \mathrm{ml}$ lactose broth. For obtaining pure culture, bacterial colonies of different agar were streaked in their respective media and incubated overnight at $37^{\circ} \mathrm{C}$. Bacteria was identified on the basis of colony characteristics, morphological characteristics by Gram's staining, sugar fermentation test and total coliform and faecal coliform counts of food sample were determined using the Most Probable Number (MPN) technique ${ }^{15}$.

\section{Data analysis}

Questionnaires were modified and tested for suitability through Cronbach's alpha test with a reliability coefficient of 0.78 . The questionnaire took approximately 15 minutes to complete.

\section{The SPSS Version}

21.0 (SPSS Inc., Chicago, IL, USA) statistical software package was used for all analyses. The results were expressed as mean \pm standard deviations $( \pm \mathrm{SD})$, frequencies, and percentages. Descriptive statistics were used to measure association between them. An independent $t$-test was applied for binary variables to compare the scores regarding street food preference according to gender, education level; age, and the frequency of consumption of street food, while a one-way ANOVA (confidence interval 95\%) was applied for more than two variables, and a post hoc LSD test was used to determine group difference. Statistical significance was identified at the $95 \%$ confidence interval $(p<0.001$ and $p<$ $0.05)$.

\section{Results}

According to the present research, the most popular street foods that are frequently consumed in Dhaka city are shown in Table 1. 
In this study it was found that shingara $(n=411,63.72 \%)$, samucha ( $\mathrm{n}=267,41.40 \%)$, puri $(\mathrm{n}=225,34.88 \%)$, and fuchka $(\mathrm{n}=216,33.48 \%)$ are the most preferred street foods among young people. Velpuri, chola, jhalmuri, chotpoti, ice-cream, chanachur, tikka kabab with paratha, shrimp kabab and fruit with salt and chilli are frequently preferred foods.

Table 1. The most preferred street foods of the youngsters $(n=$ 645).

\begin{tabular}{lcc}
\hline Item & Number & $\%$ \\
\hline Shingara & 411 & 63.72 \\
Samucha & 267 & 41.40 \\
Puri & 225 & 34.88 \\
Fuchka & 216 & 33.48 \\
Velpuri & 190 & 29.45 \\
Chola & 156 & 24.18 \\
Jhalmuri & 108 & 16.74 \\
Chanachur & 180 & 27.90 \\
Ice cream & 54 & 8.37 \\
Chotpoti & 163 & 25.27 \\
Tikka & kebab & withparatha \\
122 & 18.91 & \\
Shrimp kabab & 92 & 14.26 \\
Fruits with salt andchili & 38 & 5.89 \\
\hline
\end{tabular}

The preference scores of participants who consume street foods 1-3 times a year were the lowest $(58.3 \pm 1.0)$ and those of participants who consume it daily $(88.3 \pm 5.0)$ were the highest (Table 2).
The mean street food preference scores of males $(79.2 \pm 4.2)$ was found to be higher than females $(75.3 \pm 2.2)$ and the difference was statistically significant $(t=9.83, p<0.05)$. University students $(84.5 \pm 3.2)$ preferred consuming street foods more than high school students $(65.4 \pm 2.1)(t=24.5, p<0.05)$. The mean street food preference score $(78.3 \pm 3.2)$ was higher for 19-22 years old than for other age groups $(F=123.5, p<0.05)$. The differences between all age groups are also statistically significant $(p<0.05)$ (Table 3).

Table 4 shows that although the young consumers knew that it is easier for street food to contaminate people with microorganisms $(M=3.46 \pm 0.96, F=3.15 \pm 1.08)$, vendors paid no attention to hygiene, street foods are raw or not cooked well $(t=5.32, p<0.05)$, and consumers preferred this food because it was cheap $(p<0.05)$, tasty $(p<0.05)$, with varieties $(p<0.05)$, popular $(<0.05)$ and had fast service $(p<0.05)$. The difference in the mean scores between the genders is statistically significant $(\mathrm{p}<0.05)$.

In present study, all the six food items were examined for determination of total bacterial load and all of them were found to be contaminated. Total bacterial count in all the food items was recorded ranged from $1.0 \times 10^{7}$ c.f.u./gm to $2.4 \times 10^{7}$ c.f.u./ gm whereas highest count was found in velpuri and lowest in samucha samples. Total bacterial count (TBC) of samples from all the tested street vended restaurants were not within acceptable limit recognized by the International Commission for Microbiological Specification for Foods $\left(10^{6}\right.$ to $\left.<10^{7} \mathrm{cfu} / \mathrm{g}\right)$ (ICMSF, 2002). Velpuri had the highest number of Staphylococcus $\left(5.3 \times 10^{5}\right.$ c.f.u./gm), fuchka had the highest number of Salmonella $\left(4.1 \times 10^{5}\right.$ c.f.u./gm $)$ and jhalmuri had the highest number of E. coli $\left(4.0 \times 10^{4}\right.$ c.f.u./gm) (Table 5).

Table 2. Youngster's preference scores according to consumption frequency of street foods.

\begin{tabular}{|c|c|c|c|c|c|}
\hline Consumption frequency & $\mathrm{n}(\%)$ & Mean \pm SD & $\mathrm{F}$ & $\mathrm{p}$ value & \\
\hline Daily & 312 & $(48.37)$ & $88.3 \pm 5.0$ & & \\
\hline 2-3 times per week & 102 & $(15.81)$ & $86.4 \pm 6.0$ & & \\
\hline Weekly & 87 & (13.48) & $74.1 \pm 9.3$ & & \\
\hline 2 times per month & 69 & (10.69) & $69.0 \pm 8.3$ & 10.6 & $0.000^{*}$ \\
\hline Monthly & 58 & $(8.99)$ & $68.4 \pm 4.3$ & & \\
\hline 1-3 times a year & 17 & $(2.64)$ & $58.3 \pm 1.0$ & & \\
\hline
\end{tabular}

$*_{\mathrm{p}}<0.050$

Table 3. Street food preference scores of youngsters according to gender, education level and age (mean, standard deviation and significance level).

\begin{tabular}{llccc}
\hline Demographic characteristics & Number $(\%)$ & Mean \pm SD & $\mathrm{t} / \mathrm{F}$ test & $\mathrm{p}$ value \\
\hline Gender & Male & $258(40)$ & $79.2 \pm 4.2$ & $\mathrm{t}=9.83$ \\
& Female & $387(60)$ & $75.3 \pm 2.2$ & $\mathrm{t}=24.5$ \\
Education level & High school student & $235(36.4)$ & $65.4 \pm 2.1$ & $0.000^{*}$ \\
& University student & $410(63.6)$ & $84.5 \pm 3.2$ & $\mathrm{~F}=123.5$ \\
Age (years) & 15-18 years of age & $228(35.3)$ & $65.4 \pm 2.1$ & $0.000^{*}$ \\
& 19-22 years of age & $242(37.5)$ & $78.3 \pm 3.2$ & \\
\hline
\end{tabular}

$*=\mathrm{p}<0.05$ 
Table 4. Causes of Street Food Preference

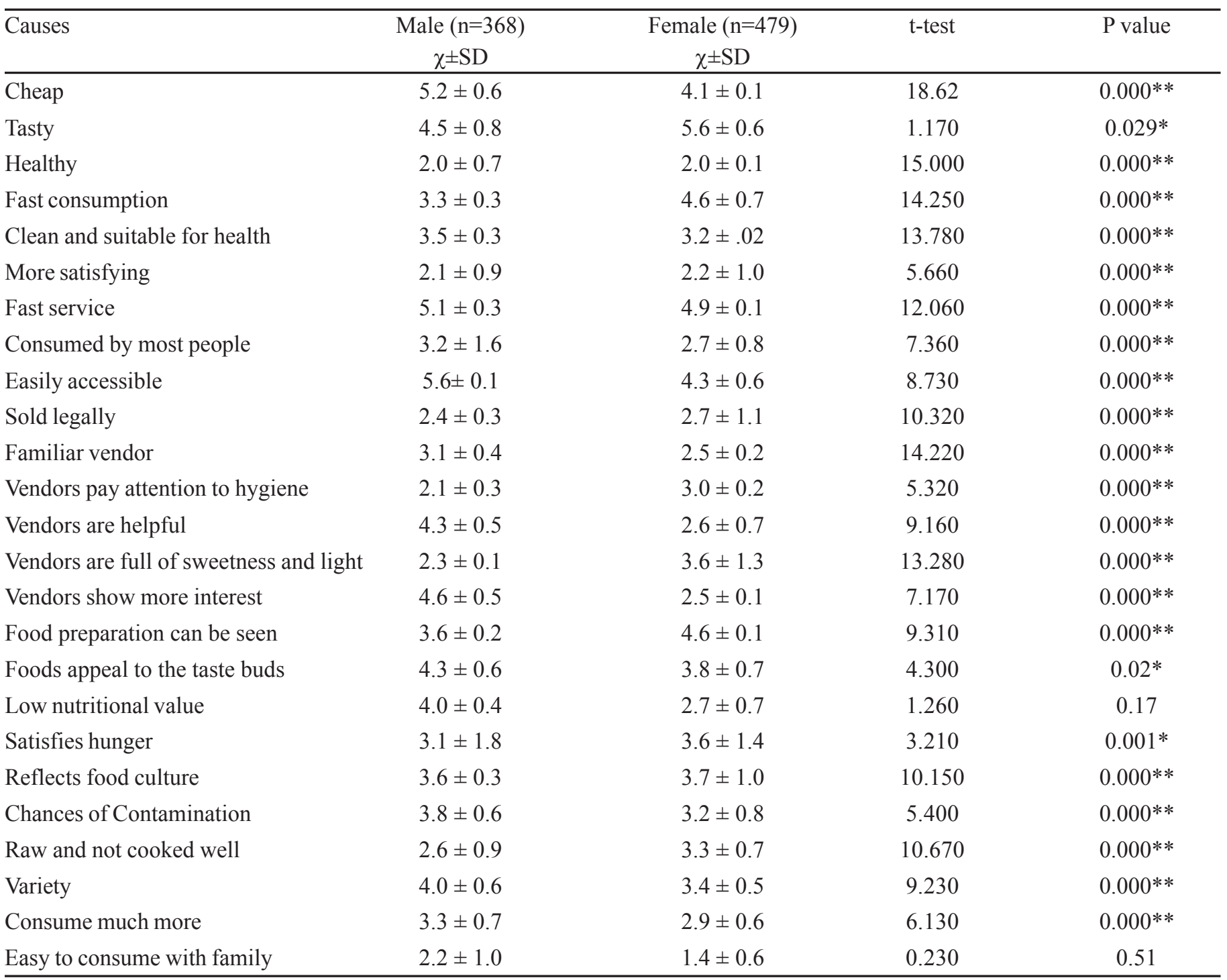

Table 5. Mean total bacteria, Staphylococcus spp., Salmonella spp. and E. coli counts in street vended fast foods in Dhaka city

\begin{tabular}{lcccc}
\hline Food items & $\begin{array}{c}\text { Total bacterial count } \\
\text { (c.f.u./gm) }\end{array}$ & $\begin{array}{c}\text { Staphylococcus } \\
\text { spp. count (c.f.u./gm) }\end{array}$ & $\begin{array}{c}\text { Salmonella spp. } \\
\text { count (c.f.u./gm) }\end{array}$ & $\begin{array}{c}\text { E. coli } \\
(\text { c.f.u./gm) }\end{array}$ \\
\hline Shingara & $1.3 \times 10^{7}$ & $1.0 \times 10^{5}$ & $3.0 \times 10^{3}$ & $2.1 \times 10^{4}$ \\
samucha & $1.0 \times 10^{7}$ & $1.5 \times 10^{5}$ & $3.1 \times 10^{3}$ & $1.0 \times 10^{4}$ \\
Puri & $1.6 \times 10^{7}$ & $3.2 \times 10^{5}$ & $2.2 \times 10^{4}$ & $1.6 \times 10^{4}$ \\
Fuchka & $2.3 \times 10^{7}$ & $3.6 \times 10^{5}$ & $4.1 \times 10^{5}$ & $2.9 \times 10^{4}$ \\
Velpuri & $2.7 \times 10^{7}$ & $5.3 \times 10^{5}$ & - & $3.8 \times 10^{4}$ \\
Chola & $1.2 \times 10^{7}$ & $3.2 \times 10^{5}$ & $1.0 \times 10^{4}$ & $3.2 \times 10^{4}$ \\
Jhalmuri & $1.6 \times 10^{7}$ & $7.1 \times 10^{4}$ & $2.2 \times 10^{4}$ & $4.0 \times 10^{4}$ \\
Chanachur & $1.5 \times 10^{7}$ & $7.3 \times 10^{4}$ & $3.4 \times 10^{4}$ & $3.9 \times 10^{4}$ \\
Chotpoti & $2.3 \times 10^{7}$ & $1.0 \times 10^{5}$ & $3.8 \times 10^{4}$ & $2.8 \times 10^{4}$ \\
kebab with paratha & $1.3 \times 10^{7}$ & $2.8 \times 10^{4}$ & DL & $1.4 \times 10^{4}$ \\
\hline
\end{tabular}

Note: According to the International Commission for Microbiological Specification for Foods (ICMSF, 2002), Acceptable range of TBC, Staphylococcus and E. coli are $10^{6}$ c.f.u./gm; $10^{4}$ c.f.u./gm; and $10^{2}$ c.f.u./gm respectively and detection of Salmonella spp. in $25 \mathrm{~g}$ sample is unacceptable. 


\section{Discussion}

Street food is preferred by mostly young consumers, especially students, due to its taste, accessibility, variety and low cost. Numerous studies have found that street food has poor hygiene, and quality ${ }^{16-17}$. Sert and Kapusuz $(2010)^{18}$ found in their study that $75 \%$ of the participants preferred street food occasionally and $18.9 \%$ usually. In the present study, the street food consumption preference scores were high in participants who consumed it daily $(F=10.6, p=0.000)$ (Table 2$)$. According to a previous study the most preferred foods were shingara, samucha, puri, and fuchka ${ }^{5}$. In the present study also, the most preferred foods were shingara $(n=411,63.72 \%)$, samucha $(n=267$, $41.40 \%)$, puri $(n=225,34.88 \%)$, and fuchka $(n=216,33.48 \%)$.

Sert et al. found that, because of their economic and fast service considerations students consumed street foods quite frequently, although they knew that these foods are unhealthy and low in nutritional value ${ }^{18}$. Similarly, in the present study although street food was widely consumed, the scores of preference causes "clean and suitable for health" and "healthy" were low. The difference according to gender was statistically significant $(p=0.000)$ (Table 4 ). Like numerous other studies, in the present study the scores of preference causes "more satisfying", "variety", "easily accessible", "food preparation can be seen", and "reflects food culture" were high. The difference between the genders was significant $(p=0.000)$ (Table 4$)^{19-21}$. The males prefer eating outside more than females. Among the vendors, $22.6 \%$ informed that they did not disinfect their hands during working and $80.2 \%$ touch food and money at the same time ${ }^{21}$. While $8-11 \%$ of the vendors did not have any information about food contamination at all. In a study carried out in India in 2014 by Sharm et al., 70\% of the 60 samples taken from street vendors were contaminated with $E$. coli and $S$. Typhimurium ${ }^{22}$. Thus, educating both vendors and consumers about food hygiene should be considered seriously, especially in the Indian subcontinent. Proper food hygiene education and adequate knowledge about food hygiene practices play an important role in the prevention of foodborne diseases around the world. In nutrition programmes in the USA, in order to provide healthy nutrition to students, training on food hygiene and safe food selection are observed in addition to their nutritional behaviour. The risk of foodborne diseases can be reduced by educating high school and university students about the importance of food safety.

In the present study, microbiological methods were used to identify bacteria from the street fast foods. The results of cultural characteristics and biochemical characteristics were used to identify the bacteria. A total of 60 isolates of three organisms were identified by cultural means. The highest number of bacteria was isolated from velpuri (13/60) and lowest number in samucha sample $(5 / 60)$. This variation might be associated with the ingredient that was used for preparation of these particular foods. In several studies conducted in street vended foods of Nigeria ${ }^{24}$, in selected street foods of Gondar town, Ethiopia ${ }^{23}$ and in street foods of Silchar city, Assam, India $(2014)^{22}$ following the similar procedure.

A risk analysis of food safety should be undertaken to educate consumers on food safety. Awareness programmes should include knowledge about the temperature control of food, proper food preparation practices, suitable cleaning and disposal procedures, causative agents of foodborne illnesses, high-risk groups, and the prevention of cross contamination. The dissemination of the messages about food safety education programmes will raise consumers' food safety knowledge and awareness about street food.

\section{Limitations}

As the population of this study consisted of young consumers from Dhaka, the results cannot be generalized for all consumers or all ages. Although the reliability coefficient found was high, interpretation of the results is limited due to responses being selfreported, which are prone to subject bias.

\section{Acknowledgements}

The authors would like to thank the young consumers for their cooperation, who agreed to participate in the study and answered the questions truthfully and wholeheartedly.

\section{Reference}

\section{Reference}

1. Food and Agriculture Organization of the United Nations (FAO). INFOSAN Information Note No. 3/2010-Safety of street vended food. [website on the Internet]. 2010 [accessed 2015 Jul 09]. Available at: http://www.who.int/ foodsafety/fs_management/ No_03_StreetFood_Jun10_en.pdf.

2. Food and Agriculture Organization of the United Nations (FAO). Food for the cities: Street foods. [website on the Internet]. 2013 [accessed 2015 Nov 12] Available at: http://www.fao.org/fcit/food-processing/street-foods/ en/.

3. Choudhury M, Mahanta LB, Goswami JS, Mazumder MD. 2011. Will capacity building training interventions given to street food vendors give us safer food?: A cross-sectional study from India. Food Control, 22(8):1233-1239.

4. Lucca A, Torres EAFS. 2006. Street-food: the hygiene conditions of hotdogs sold in São Paulo, Brazil. Food Control, 17(4):312-316.

5. Muinde OK, Kuria E. 2005. Hygienic and sanitary practices of vendors of street foods in Nairobi, Kenya. African J Food Agriculture and Nutritional Development (AJFAND), 5(1):1-14.

6. World Health Organization (WHO). Basic steps to improve safety of streetvended food. International Food Safety Authorities Network (INFOSAN), Information Note No.3/2010 - Safety of street-vended food. [website on the Internet]. 2010 [accessed 2015 Aug 08] Available at: http:// w w w. who.int/foods a f e t y/f s_ man a ge ment/ No_03_StreetFoodJun10_en.pdf

7. Abdallah M, Mustafa NEM. 2010. Bacteriological quality of street-vended Um-Jinger: a traditional Sudanese food. Intern J. Food Safety, 12:16-19.

8. Biswas S, Parvez MAK, Shafiquzzaman M, Nahar S, Rahman MN. 2010. Isolation and characterization of Escherichia coli in ready-to-eat foods vended in Islamic University, Kushtia. J. Bio-Science; 18(1):99103.

9. Tabashsum Z, Khalil I, Nazimuddin MD, Mollah AKM, Inatsu Y, Bari ML. 2013. Prevalence of foodborne pathogens and spoilage microorganisms and their drug resistant status in different street foods of Dhaka city. Agric. Food Anal. Bacteriol. J. 3: 281-292. 
10. Nicolas B, Razack BA, Yollande I, Aly S, Tidiane OCA, Philippe NA, Comlan DS, Sababénédjo TA. 2007. Street-vended foods improvement: Contamination mechanisms and application of Food Safety Objective Strategy: Critical review. Pak. J. Nutr., 6: 1-10.

11. Dawson RJ and C Canet. 1991. International activities in street foods. Journal of Food Control.,

12. Bryan FL, Michanie SC, Alvarez P and Paniagua A, 1988b. Critical control points of street-vended foods in the Dominican Republic. $J$ of Food Protection, 51: 373-383.

13. Clarence SY, Obinna CN., Shalom NC. 2009. Assessment of bacteriological quality of ready to eat food (Meat pie) in Benin City metropolis, Nigeria. Afr.J. Microbiol Res., 3: 390-395.

14. Qadri F, Svennerholm AM, Faruque AS and Sack RB, 2005. Enterotoxigenic Escherichia coli in developing countries: Epidemiology, microbiology, clinical features, treatment and prevention. Clinical Microbiology. 18: 465-483.

15. Cheesbrough M. 2006. District laboratory practice in tropical countries. Cambridge university press.

16. Mamun MA, Rahman M, Turin TC. 2013. Microbiological quality of selected street food items vended by schoolbased street food vendors in Dhaka, Bangladesh. Intern J. Food Microbiology, 166(3): 413418.

17. Nunes BN, Cruz AG, Faria JAF, Anderson SSA, Silva R, Moura MRL 2010. A survey on the sanitary condition of commercial foods of plant origin sold in Brazil. Food Control, 21(1):50-54.
18. Sert S, Kapusuz F. 2010. Street foods: research on students' opinions and reasons for preferring. Electronic J. Food Technologies. 5(3):25-35.

19. Hanashiro A, Morita M, Matte GR, Matte MH, Torres EAFS. 2005. Microbiological quality of selected street foods from a restricted area of Sao Paulo City, Brazil. Food Control. 16(5):439-444.

20. Aluko OO, Ojeremi TT, Olakele DA, Ajidagba EB. 2014. Evaluation of food safety and sanitary practices among food vendors at car parks in Ile Ife, southwestern Nigeria. Food Control. 40:165-171.

21. Silva SA, Cardoso RCV, Góes JAW, Santos JN, Ramos FP, Jesus RB, Vale RS, Silva PST. 2014. Street food on the coast of Salvador, Bahia, Brazil: A study from the socioeconomic and food safety perspectives. Food Control. 40:78-84

22. Sharma I, Mazumdar JA. 2014. Assessment of bacteriological quality of ready to eat food vended in streets of Silchar city, Assam, India. Indian J. Med. Microbiol. 32: 169-171.

23. Adimasu A, Mekonmen B, Guadu T, Gizaw Z, Adane T. 2016. Bacteriological quality assessment of selected street foods and their public health importance in Gondar Town, North West Ethiopia. Glob Vet. 17:255264.

24. Akusu OM, Kiin-Kabari DB, Wemedo SA. 2016. Microbiological quality of selected street vended foods in Port Harcourt metropolis, Rivers State, Nigeria.Sky J. Food Sci. 5: 8-11. 